\title{
A Critical Review on Mathematical Descriptions to Study Flux Processes and Environmental-Related Interactions of Mangroves
}

\author{
Jefferson Brooks ${ }^{1,2} \mathbb{D}$, Miguel Chen Austin ${ }^{1,2,3} \mathbb{D}$, Dafni Mora ${ }^{1,2,3} \mathbb{D}$ and Nathalia Tejedor-Flores ${ }^{1,2,3,4, * \mathbb{D}}$ \\ 1 Research Group in Energy and Comfort in Bioclimatic Buildings (ECEB), Faculty of Mechanical Engineering, \\ Universidad Tecnológica de Panamá, Panama City 0819-07289, Panama; jefferson.brooks@utp.ac.pa (J.B.); \\ miguel.chen@utp.ac.pa (M.C.A.); dafni.mora@utp.ac.pa (D.M.) \\ 2 Sistema Nacional de Investigación (SNI), Panama City 0816-02852, Panama \\ 3 Centro de Estudios Multidisciplinarios en Ciencias, Ingeniería y Tecnología (CEMCIT-AIP), \\ Panama City 0819-07289, Panama \\ 4 Centro de Investigaciones Hidráulicas e Hidrotécnicas (CIHH), Universidad Tecnológica de Panamá, \\ Panama City 0819-07289, Panama \\ * Correspondence: nathalia.tejedor@utp.ac.pa; Tel.: +507-6077-1870
}

check for updates

Citation: Brooks, J.; Chen Austin, M.; Mora, D.; Tejedor-Flores, N. A Critical Review on Mathematical Descriptions to Study Flux Processes and Environmental-Related Interactions of Mangroves. Sustainability 2021, 13, 6970. https://doi.org/10.3390/ su13126970

Academic Editors: Fatemeh Kamali and Teodor Rusu

Received: 29 April 2021

Accepted: 17 June 2021

Published: 21 June 2021

Publisher's Note: MDPI stays neutral with regard to jurisdictional claims in published maps and institutional affiliations.

Copyright: (c) 2021 by the authors. Licensee MDPI, Basel, Switzerland. This article is an open access article distributed under the terms and conditions of the Creative Commons Attribution (CC BY) license (https:/ / creativecommons.org/licenses/by/ $4.0 /)$.

\begin{abstract}
Trees are resources that provide multiple benefits, such as the conservation of fauna, both terrestrial and marine, a source of food and raw material, and offering protection in storms, which makes it practical to understand their behavior against different phenomena. Such understanding may be possible through process modeling. Studies confirm that mangrove forests can store more carbon than other forests, influencing the fight against global warming. Thus, a critical and systematic review was carried out regarding studies focusing on mangroves to collect information on the models that have been applied and the most influential variables highlighted by other authors. Applying a systematic search for the most relevant topics related to mangroves (basic as well as recent information), it is possible to group models and methods carried out by other authors to respond to certain behaviors presented by mangroves. Moreover, possible structuring of a mathematical model applied to a species of interest thanks to the analyzed references could provide justified information to the authorities on the importance of these forests and the benefits of their preservation and regeneration-recovery.
\end{abstract}

Keywords: carbon storage; carbon dioxide sequestration; mangrove; mathematical model

\section{Introduction}

Over the years, concern about climate change has grown to the point where industries and any other activity are looking for ways to make themselves more efficient and environmentally friendly. The increase in the Earth's average temperature causes the modification of multiple ecosystems, affecting the species subsisting in it and the effect on the growth of multiple crops due to the carbon dioxide $\left(\mathrm{CO}_{2}\right)$ concentrations levels in the air [1]. In addition, the increase in the planet's temperature stimulates the melting of permafrost, causing the release of large amounts of trapped $\mathrm{CO}_{2}$ and methane [2]. Trees play an essential role in the capture and retention of $\mathrm{CO}_{2}$, the gas necessary to carry out part of its regeneration, growth, and maintenance processes during its life, having the possibility of increasing their $\mathrm{CO}_{2}$ storage capacity, depending on the conditions of the tree (humidity, $\mathrm{CO}_{2}$ concentration, nutrients, among others) [3].

This study aims to provide information on the equations that have been used recently to study the behavior of trees, specifically mangroves, providing information to other readers about the most relevant works in the determination of stored carbon and the most influential variables. The research focuses on the works presented in the last five years, including some works developed outside this limit, to then select the research focused on the retention of $\mathrm{CO}_{2}$ in mangrove ecosystems, trying to show a better panorama of the variables involved than allowed by more comprehensive assessments of the importance of mangroves. 
Trees near the coasts (in direct contact with salt and fresh water) are called mangroves. This kind of tree provides multiple benefits for the development of many species and the humans that live near these coastal areas [4]. These trees have the characteristic of capturing much more $\mathrm{CO}_{2}$ than the species that are in contact with fresh water (much further from the coast) due to the characteristics of the soil, but they do not have the same number of studies due to the lack of accessibility to perform them [4,5]. Mangroves have managed to adapt to salt water and freshwater ecosystems thanks to the morphological adaptations they have developed, such as glands that allow them to expel excess salt, detachment of the seed once mature and ready to settle, and aerial roots for a greater fixation on their muddy soils, among others $[4,6]$.

Mangroves also protect the coasts from strong winds and waves, dissipating the energy generated by their physical characteristics (such as their abundant roots and leaves) [4], also influencing the attenuation of cyclonic winds [7] and carbon fixation both in the soil and its biomass [8,9]. To survive the extreme environmental conditions, they developed unique ecophysiological characteristics [10-16] for functions such as leveling the salt concentration inside, water flow, and gas exchange [17]. In the following sections, various equations that characterize mangroves are evaluated. Through the evaluation, it was observed that in many cases, each species of tree has characteristics for which the equations developed for that species would not precisely give the same results if they were applied in another species with different configurations.

The text is divided into five main sections; Section 1 contains a brief introduction to the topic, Section 2 presents the methodology used, Section 3 contains the main results, and Sections 4 and 5 presents the discussions and conclusions of this research.

\section{Methodology}

\subsection{Literature Search Strategy}

This work was based on bibliographic research on the mathematical models that have been developed to explain specific processes in trees oriented towards mangrove species. A search was carried out on the research published from 2016-2021 to record updated information involving mangroves. Two codes were used to extract information regarding the mangroves to perform the analysis, "(Tree AND Mangrove) AND (Model OR Modeling)" and "(Tree AND Mangrove) AND (Model OR Modeling AND sequestration)", named C1 and C2, respectively, in Figure 1, obtaining a total of 2629 articles. These 2629 articles were obtained after searching for these keywords on the MDPI, IEEE Xplore, Elsevier, and Springer platforms (Figure 1), and then a more exhaustive review and evaluation of these articles was carried out as described in Section 2.2.

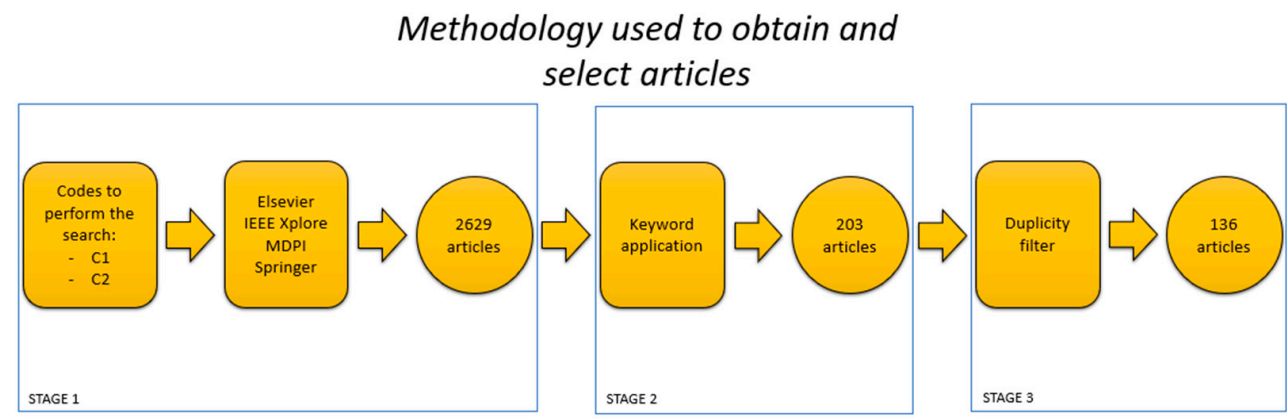

Figure 1. Methodology applied in the selection of articles. Source: Own elaboration.

\subsection{Bibliometric Analysis}

To structure stage 2, Software Rstudio (version 1.3.1093, Boston, MA, USA. Available online: https: / /www.rstudio.com/, accessed on 10 June 2021) was used, which, employing a code, extracted the articles mainly related to the topics of interest of the research such as: catchment, water flows, sap and/or carbon, carbon dioxide, regeneration, and flooding. 
The code searched the topics of interest in the title, abstract, and keywords of the articles that were in the database. Among the packages used in the Software are "bib2df" and "ggplot2." Analyzing the results generated by the code, a distribution was observed that, for the most part, corresponds to issues related to $\mathrm{CO}_{2}$, followed by catchment, and flows in mangroves, as shown in Figure 2. It was also possible to observe the number of publications that relate $\mathrm{CO}_{2}$ to mangroves according to the database obtained since 2016 in Figure 3.

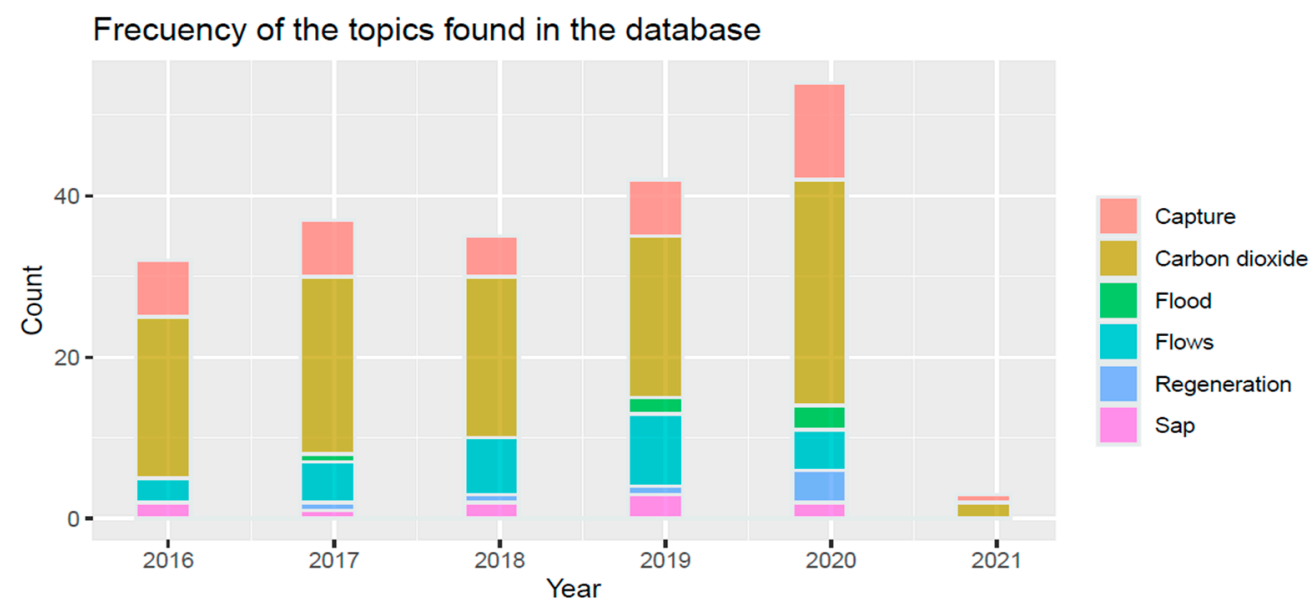

Figure 2. Frequency of the topics found in the database. Source: Own elaboration.

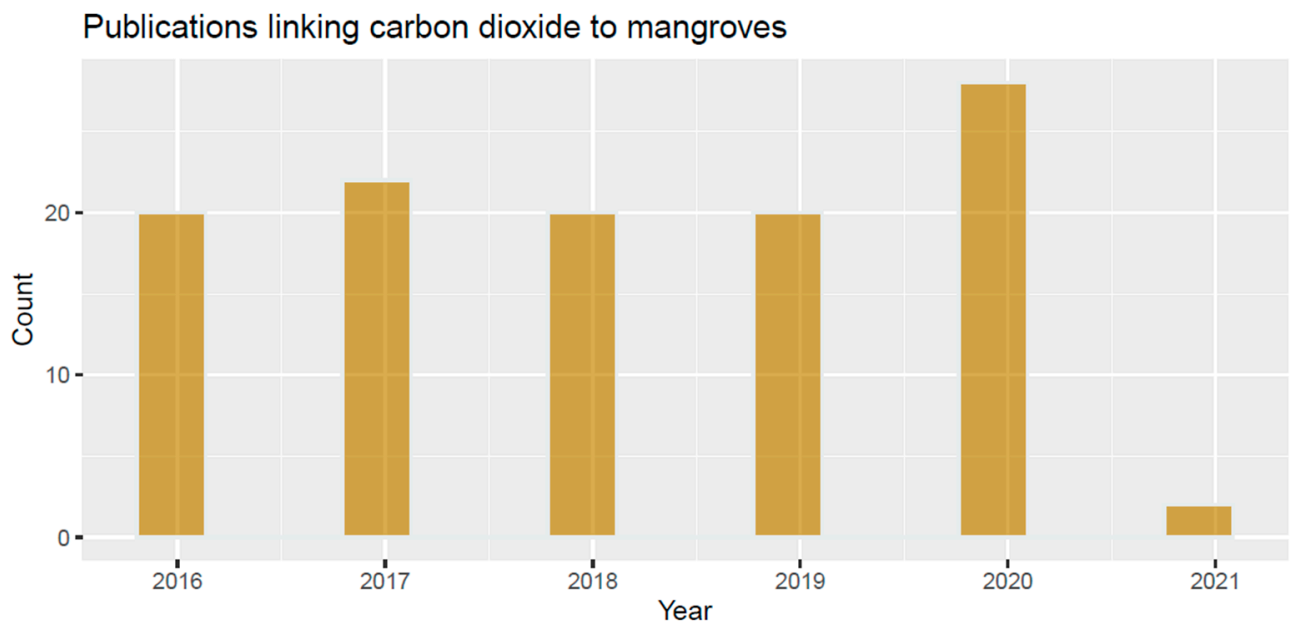

Figure 3. Publications on $\mathrm{CO}_{2}$ and mangroves. Source: Own elaboration.

The topics most found in the resulting database are structured in Table 1, shown below.

Table 1. Topics found in the database.

\begin{tabular}{cc}
\hline Topics & Reference \\
\hline Carbon stored by remote sensing/satellite images & {$[18-33]$} \\
Monitoring of stored carbon & {$[5,34-40]$} \\
Carbon quantification through literature & {$[41-45]$} \\
Mangrove flows & {$[46-49]$} \\
Filtration of heavy metals and pollutants & {$[50,51]$} \\
\hline
\end{tabular}

Source: Own elaboration.

\section{Results: Relevance of Mangroves Modeling to Reap Their Benefits}

This section presents the studies found regarding the mathematical modeling of mangroves' characteristics or aspects. Only four aspects regarding mangroves' habilities 
or benefits were found and are classified as follows: depollution, biomass content, carbon sequestration, and rate of growth.

\subsection{Depollution}

Regarding depollution, only one reported study was found involving mathematical descriptions. The study developed by Ray et al. [50] analyzed the purification properties of the mangrove by performing tests in an empirical model to determine the uptake of vanadium, tantalum, and niobium in the soil, roots, and leaves of eight mangrove species by extracting samples from the Indian Sundarbans in the northeast of the Indian peninsula. Multiple types of equipment were used in the laboratory to transform the samples into data that could be used for the following equations (see Table A1 in Appendix A for nomenclature):

$$
\begin{gathered}
\log [\text { metal }]=b \times \delta 13 C+a \\
B A F=\text { metal }_{\text {leaf }+ \text { wood }+ \text { root }} / \text { metal }_{\text {sediment }} \\
T F=\text { metal }_{\text {leaf }+ \text { wood }} / \text { metal }_{\text {root }} \\
E F=\left\{(\text { metal } / H f)_{\text {leaf }+ \text { wood }+ \text { root }}\right\} /\left\{(\text { metal } / H f)_{\text {sediment }}\right\}
\end{gathered}
$$

The results indicate that there is a retention of these elements in the different parts of its structure. Such results can be found in the author's article for the different mangrove species analyzed. Error or correlation data were not presented in the study.

\subsection{Biomass Content}

There are multiple studies focused on determining the biomass content in tropical forests to know the carbon storage capacity they possess, and with this, the importance they represent in the fight against global warming. Within the studies that focused on the calculation of biomass, there was a certain tendency regarding allometric models that involved measurements in the field for their use, mostly the product of correlations between the variables. Such is the case of Lozano [17], Mohd Zaki et al. [52], Da Motta et al. [53],

\begin{tabular}{|c|c|c|c|c|c|}
\hline Author & Equation & & Species & $\mathrm{T}\left({ }^{\circ} \mathrm{C}\right)$ & $\begin{array}{c}\text { Mean } \\
\text { Annual } \\
\text { Rainfall } \\
\left(\mathrm{mm} \mathrm{y}^{-1}\right)\end{array}$ \\
\hline Mohd zaki et al. [52] & $A G B=\exp \left[\left[-1.803-0.976 \times E+0.967 \times \ln \left(\rho_{e}\right)+2.673 \times \ln (D B H)-0.0299 \times\left[\ln (D B H)^{2}\right]\right]\right]$ & $(5)$ & L.t.t.s. & $22.9-27.7$ & 2178 \\
\hline Da Motta et al. [53] & $A G B=0.251 \times \rho_{e} \times D B H^{2.46}$ & (6) & $\begin{array}{l}\text { L.r.-R.m. } \\
\text { A.s. }\end{array}$ & - & 1320 \\
\hline Van Vinh et al. [54] & $A G B=0.38363 \times D B H^{2.2348}$ & (7) & R.a. & 27 & 1800 \\
\hline Simpson et al. [55] & $\ln (A G B)=1.63 \times \ln \left(D_{0}\right)+1.3545 \times \ln (H)-2.8853$ & $(8)$ & $\begin{array}{l}\text { L.r.-A.g. } \\
\text { R.m. }\end{array}$ & $21-29$ & - \\
\hline Chatting et al. [56] & $\begin{array}{c}\log (A G B)=2.14 \times \log (C D)+0.20 \\
C D=0.3831 \times D B H+0.6863\end{array}$ & (9) & A.m. & - & 54 \\
\hline Kelleway et al. [57] & $A G B=\frac{h \times[0.214 \times(D B H \times \pi)-0.113]^{2}}{10}$ & (10) & A.m. & - & 1084 \\
\hline Clough et al. [58] & $\log (A G B)=A+(B \times \log (D B H))$ & (11) & R.s.-A.m. & 35 & 1750 \\
\hline \multirow[t]{2}{*}{ Prasanna et al. [59] } & $\begin{array}{c}V=\frac{h}{6} \times\left(A_{b a}+4 \times A_{m}+A_{t}\right) \\
L_{d b}=\sum_{j=1}^{i} n_{j} \times L w_{j} \times N_{j}\end{array}$ & $\begin{array}{l}(12) \\
(13)\end{array}$ & \multirow[t]{2}{*}{ A.m. } & \multirow[t]{2}{*}{$28-34.2$} & \multirow[t]{2}{*}{-} \\
\hline & $B_{d b}=\sum_{j=1}^{i} n_{j} \times b w_{j}$ & (14) & & & \\
\hline Makinde et al. [60] & $A G B=e^{(-3.1141+0.9719 \ln (D B H \times h))}$ & (15) & $\begin{array}{l}\text { T.g.-G.a. } \\
\text { I.e. }\end{array}$ & - & 1850 \\
\hline
\end{tabular}
Van Vinh et al. [54], Simpson et al. [55], and Chatting et al. [56], among others, who did not use the same equations but had variables in common (see Table 2).

Table 2. Allometric equations focused on the determination of aboveground biomass.

With: L.T.T.S. (lowland tropical tree species), L.R. (Laguncularia racemosa), R.a. (Rhizophora apiculata), A.g. (Avicennia germinans), R.m. (Rhizophora mangle), A.s. (Avicennia schaueriana), A.m. (Avicennia marina), R.s. (Rhizophora stylosa), T.g. (Tectona grandis), G.a. (Gmelina arborea), and I.s. (Indigenous species [60]). Source: Own elaboration. 
Mohd Zaki et al. [52] presented equations that help reduce uncertainty when estimating carbon stored in forests, including equation (5) (Table 2), calculating the aboveground biomass (AGB) using remote sensing and non-linear regression equations in tropical lowland. The study was carried out in Hutan Simpan Ayer Hitam, a Malaysian forest reserve, which had information collected since 2013, and then the researchers carried out another more recent scan and thus completed the information necessary to apply the study. The equation used considers the density of tree species $\left(\rho_{\mathrm{e}}\right)$, as well as the diameter at breast height $(\mathrm{DBH})$. Within the results, there were slightly low values in the determination coefficient $\left(\mathrm{R}^{2}=0.453\right)$ between the existence of carbon and the crown projection area, although its correlation turned out to be higher $(0.671)$, attributing the values to the irregularities present in the canopy of the forest being studied.

Da Motta et al. [53] carried out a study in southeastern Brazil on the banks of the Piraquê-Açu river to determine the AGB and the carbon stored by the mangroves. They were able to obtain results by using allometric equations such as (6) (Table 2), taking measurements in the trees present in an area of $600 \mathrm{~m}^{2}$ and soil samples to identify aspects such as humidity, permeability, and granulometry, among others. This study obtained 2.92 tons of AGB per hectare $\left(\mathrm{t} \mathrm{ha}{ }^{-1}\right.$ ) and $1.46 \mathrm{t} \mathrm{ha}^{-1}$ of carbon, with a coefficient of determination, for the mangrove species Laguncularia racemosa, which was satisfactory for the author $\left(\mathrm{R}^{2}=0.89\right)$. For the determination of $A G B$, an equation involving the density of the wood and the DBH was used, while for the stored carbon, the literature was used depending on the type and quantity of species found in the analyzed area.

Van Vinh et al. [54] focused their research on mangroves in Southern Vietnam, with the objective of determining the stored biomass through a proposed allometric equation (Equation (7)) that involves DBH, resulting in values between 59.7 and $230.9 \mathrm{mgC} \mathrm{ha}^{-1}$. Additionally, distributions of carbon storage in biomass were assigned: $77.11 \%$ for the trunk, $11.87 \%$ for the branches, and $11.02 \%$ between roots and leaves with a coefficient of determination $\mathrm{R}^{2}$ of 0.976 with a standard error value of 1.17 . Simpson et al. [55] worked on the Atlantic coast of Florida, USA to identify the three-year changes concerning carbon storage due to the invasion of mangrove species in marsh areas thanks to Equation (8), using height of the tree in centimeters $(\mathrm{H})$ and the diameter just after the soil surface $\left(\mathrm{D}_{0}\right)$. This work did not present correlation data or percentage of error. Chatting et al. [56] analyzed a mangrove area in Qatar, where the species Avicennia marina was prevalent, generating the Equation (9) used to determine the existing AGB by means of crown diameter (CD) and $\mathrm{DBH}$. The equation used to determine AGB had a correlation coefficient of 0.94 , while the equation used to convert $\mathrm{DBH}$ into $\mathrm{CD}$ had $\mathrm{R}^{2}=0.53$.

The data collection for Mohd Zaki's work was carried out through non-destructive testing, unlike the study developed by Kusmana et al. [61], who conducted destructive tests on 30 tree samples in the mangroves of Cilacap, Indonesia. Within the study, the equations developed to obtain values of aboveground and underground biomass of the mangrove species Sonneratia spp. were observed, which required the DBH, height in meters (h), and density of the wood. For their part, Kelleway et al. [57] analyzed two mangroves located in marshes in southeastern Australia to quantify changes in mangrove migration to areas corresponding to salt marshes over 70 years. Aerial photographs from different years were used to make comparisons in vegetation, together with field measurements to determine AGB through allometric equations (Equation (10)) using height and DBH. The model was used in two places, obtaining a unified $\mathrm{R}^{2}$ value of 0.603 . Clough et al. [58] also provided experimental expressions for estimating AGB in mangroves on the north and west coast of Australia (Equation (11)) to determine the differences in the amount of biomass that exists due to environmental variations with $\mathrm{DBH}$ and height. The model used varied in the correlation coefficient depending on the species analyzed: for Rhizophora stylosa, there was an $\mathrm{R}^{2}$ of 0.96 with a standard error of 0.090 , while for the Avicennia marina, there was an $\mathrm{R}^{2}$ of 0.969 with a standard error of 0.091 .

Prasanna et al. [59] applied Equations (12)-(14) in the Karankadu mangrove swamp in southeastern India. These equations were sectioned in a tree to analyze each biomass 
contribution and then summations were applied, taking into account the base, middle, and top areas of the trunk $\left(A_{b a}, A_{m}\right.$, and $A_{t}$, respectively), dry leaf biomass $\left(L_{d b}\right)$, and dry branch biomass $\left(\mathrm{B}_{\mathrm{db}}\right)$. A positive correlation was obtained between AGB and DBH $\left(R^{2}=0.960\right)$, but it was not significant with respect to height $\left(R^{2}=0.349\right)$.

Makinde et al. [60] applied geospatial techniques to determine the aboveground and underground biomass through the non-destructive method, interpreting the information provided by said method and applying Equation (15). In Table 2, it is possible to observe the allometric equations, mainly focused on the estimation of AGB.

The aforementioned works ([17,52-61]) used equations that estimate the AGB of a single tree. To determine the AGB of a forest, it will be necessary to carry out an inventory to obtain the measurements and then multiply by the number of trees. In Table 3, the parameters most used by the different authors for the determination of AGB can be observed.

Table 3. Parameters used in the equations to determine the AGB.

\begin{tabular}{cccccccccc}
\hline \multicolumn{10}{c}{ Reference } \\
\hline Parameter & {$[52]$} & {$[53]$} & [54] & [55] & [56] & [57] & [58] & [59] & [60] \\
\hline$D B H$ & $*$ & $*$ & $*$ & & $*$ & $*$ & $*$ & $*$ & $*$ \\
$D_{0}$ & & & & $*$ & & & & & \\
$E$ & $*$ & & & & & & & & \\
$\rho_{\mathrm{e}}$ & $*$ & $*$ & $*$ & & & & & & \\
$H$ & & & & $*$ & & & & & \\
$C D$ & & & & & & $*$ & & & \\
$V$ & & & & & & & $*$ & & $*$ \\
$\mathrm{~h}$ & & & & & & & & $*$ & \\
\hline
\end{tabular}

Source: our elaboration.

\subsection{Carbon Sequestration}

Thanks to an inventory developed by the Management Plan of the Guapi-Iscuandé Integral Management Unit (UMI) in Colombia, Lozano [17] managed to apply an empirical model to determine the $\mathrm{CO}_{2}$ fixed in the selected mangrove, by means of Equation (18), shown in Table 4. For their part, Marchio et al. [62] selected two mangrove streams in southwest Florida, with the difference that one of these streams was hydrologically altered by human presence (dredging, channeling, polluted stormwater, compartmentalization of water flows, etc.) to determine the differences between carbon sequestration and the properties of sediments in mangroves once they are disturbed, thanks to Equation (17). As a result, it was possible to show the negative impact in terms of carbon sequestration as a result of the modification of its ecosystem. Neither paper presented had information on the percentage of error or correlation.

Table 4. Allometric equations focused on other objectives mangrove.

\begin{tabular}{|c|c|c|c|c|c|c|}
\hline Author & Equation & & Species & $\begin{array}{c}\mathrm{T} \\
\left({ }^{\circ} \mathrm{C}\right)\end{array}$ & $\begin{array}{c}\text { Mean Annual } \\
\text { Rainfall }\left(\mathrm{mm} \mathrm{y}^{-1}\right)\end{array}$ & Objective \\
\hline Lozano [17] & $C_{f}=K \times A_{b} \times\left[B_{i}+\left(G_{y} \times t\right)\right]$ & (16) & R.s.-A.m. & 26 & - & \multirow{2}{*}{$\begin{array}{c}\text { Carbon } \\
\text { sequestration }\end{array}$} \\
\hline Marchio et al. [62] & $C_{\text {seq }}=A_{d} \times B D \times C_{\text {conc }}$ & (17) & A.g.-L.r. R.m. & 23.6 & 1346 & \\
\hline Chatting et al. [56] & $\log (B G B)=2.67 \times \log (C D)-0.11$ & (18) & A.m. & - & 54 & \multirow{2}{*}{$\begin{array}{l}\text { below ground } \\
\text { biomass }\end{array}$} \\
\hline Makinde et al. [60] & $B G B=0.2 \times A G B$ & (19) & T.g.-G.a. I.e. & - & 1850 & \\
\hline Rodriguez et al. [6] & $A G=\frac{G_{y} \times D B H \times\left(\frac{1-D B H \times H}{D_{M a x} \times H_{M a x}}\right)}{274+3 \times b_{2}-4 \times b_{3} \times D B H^{2}} \times S \times n \times t_{e} \times r_{e l}$ & (20) & R.m.-A.g. L.r. & 26.6 & 2300 & $\begin{array}{l}\text { Annual } \\
\text { mangrove growth }\end{array}$ \\
\hline
\end{tabular}

Source: Own elaboration.

Table 4 presents the allometric equations applied to the determination of carbon storage in other sections of the mangrove, as well as an equation focused on the growth of mangroves. 


\subsection{Rate of Growth}

Among the works focused on growth is Rodríguez et al. [6], which was developed in the Ciénaga Grande de Santa Marta mangroves in Colombia. A code written in " $\mathrm{C}$ " language was used with 16 years of information-gathering through monitoring. An individual-based model (IBM) was applied because it generates quite accurate results, taking into account how variable and complex mangrove ecosystems are according to the author, using Equation (20) (Table 4) analyzing three mangrove species: Laguncularia racemosa, Rhizophora mangle, and Avicennia germinans.

Once the model was applied in the selected areas, it was possible to observe how vulnerable the species were to high concentrations of salinity, unlike Avicennia germinans, which continued to grow and produce new seedlings over time. In the end, the model presented the increase in the basal area that would be expected in the following years, varying the concentration of salinity or maintaining them. The work did not present information on percentage of error or correlation.

In order to better understand the equations presented, dimensional analysis was used to verify dimensional homogeneity, as well as the interrelationships of the quantities that compose them. The Rayleigh method was applied to each of the equations as shown below:

$$
\begin{gathered}
A G B=\exp \left[\left[-1.803-0.976 \times E+0.967 \times \ln \left(\rho_{e}\right)+2.673 \times \ln (D B H)-0.0299 \times\left[\ln (D B H)^{2}\right]\right]\right] \\
A G B=f\left(\rho_{e}, D B H\right)
\end{gathered}
$$

with $A G B(\mathrm{~kg}), \rho_{e}\left(\mathrm{~g} \cdot \mathrm{cm}^{-3}\right)$, and $D B H(\mathrm{~cm})$. Following the steps of the Rayleigh method, the fundamental dimensions were used:

$$
\begin{aligned}
& A G B=\alpha \times \rho_{e}{ }^{a} \times D B H^{b} \\
& M=M^{0} \times\left(M L^{-3}\right)^{a} L^{b}
\end{aligned}
$$

where $M$ is for mass, $L$ for length, and $t$ for time. Developing for $M$ and $L$, we obtained $a=1$ and $b=3$.

Then:

$$
A G B \propto \rho_{e} \times D B H^{3}
$$

This procedure was carried out for each of the equations presented in Tables 2 and 4 , but not all of them achieved a consistent result; however, it is to be expected that some expressions do not make physical dimensional sense among the variables they relate to. The results of the dimensional analysis are presented in Table 5 .

Table 5. Dimensional analysis of equations.

\begin{tabular}{cccc}
\hline Equation & Parameters & Fundamental Dimensions & Result Using Rayleigh's Method \\
\hline $\begin{array}{c}(5) \\
(6)\end{array}$ & $\rho_{e}, D B H$ & $M, L$ & $A G B \propto \rho_{e} \times D B H^{3}$ \\
\hline$(12)$ & $h, A_{b a}, A_{m}, A_{t}$ & $L$ & $V \propto \frac{h \times A_{b a} \times A_{m}}{A_{t}}$ \\
\hline$(13)$ & $L w_{j}$ & $M$ & $L_{d b} \propto L w_{j}$ \\
\hline$(14)$ & $b w_{j}$ & $M$ & $B_{d b} \propto b w_{j}$ \\
\hline$(16)$ & $A_{b}, B_{i}, t$ & $M, L, t$ & $C_{f} \propto B_{i}$ \\
\hline$(17)$ & $A_{d}, B D, C_{c o n c}$ & $M, L, t$ & $C_{s e q} \propto A_{d} \times B D$ \\
\hline$(19)$ & $A G B$ & $M$ & $B G B \propto A G B$ \\
\hline
\end{tabular}

Source: Own elaboration.

\section{Discussion}

The conditions in which the works are carried out turn out to be influential when making comparisons or selecting a model to replicate it elsewhere. Precipitation, as well as 
the temperature and fresh water that reaches the mangrove, help to stabilize the salinity of the environment, in this way the trees do not suffer from physiological stress, which would reduce the carbon retention capacity of the forest [62].

The authors agreed on the use of the variable DBH when determining AGB. However, all these expressions (Tables 2 and 4 ) result from experimental correlations and may limit their implementation in studies with different conditions and species. This means that each author who wishes to study or determine AGB for a certain mangrove species may have to carry out the process to obtain their corresponding regressions before estimating the total AGB in the mangrove. In fact, it could be said that only Equations (12-15) do not seem to depend strictly on a case study to obtain a way to estimate AGB. This is because they use common variables to any mangrove species and mangrove distribution. However, the foregoing does not exonerate us from the need to measure the diameter and height of the mangrove by incurring invasive studies of the mangrove ecosystem.

Moreover, most of the expressions indicated that the relationship between AGB and DBH is not linear. They show that the amount of AGB available increases exponentially when the DBH value increases, which leads us to infer a maximum amount of AGB; even if the DBH increases, the AGB available might not be significantly higher as one may expect. Moreover, these equations indicate that any amount of AGB cannot be obtained when DBH equals zero as expected, except for Equations (9), (12), and (17), but the resulting AGB value remains irrelevant.

The relationship between $\mathrm{AGB}$ and $\mathrm{H}$ (or h) seems to be less critical for the analyzed studies, except for Equations (8), (10), and (15). In the case of Equation (8), they used height to structure their equation because the species in the study area did not exceed $1.3 \mathrm{~m}$ in height to work with the DBH, so they decided to work with the diameter of the trunk right after the ground surface and its height. In Equation (10), the level of accuracy could be increased if the height of the tree was included since, in this study, there were trees above $2 \mathrm{~m}$ in height. It is not possible to say the same for Equation (15) because they did not work with mangroves. Instead, other morphologies and different dimensions were employed, and thus, the height could play a fundamental role in determining AGB.

The fact that $C D$ is less considered in the estimation of AGB could indicate that the use of DBH considerably simplifies the calculations for obtaining the AGB. Such a selection could reduce the number of processes to be performed for the final determination of the AGB. This estimate would contribute greatly to show the importance of these forests in the fight against global warming through carbon sequestration and the benefits for marine fauna.

The structures of Equations (6) and (7) differ in the participation of the density of the tree species analyzed. For Equation (7), it is not important to consider density since they only focused on one mangrove species, in this case, Rhizophora apiculata, while Equation (6) was developed for three mangrove species. Hence, it would give a greater approximation of the aerial biomass if the density of the analyzed wood was considered.

Comparing the equations for carbon sequestration, it was observed that Equation (17) appears to be much more complete because it accounts for the carbon present in the soil $C_{\text {conc }}$, while Equation (16) focuses only on the AGB. However, if Equation (19) is considered, a less complicated approximation of the total uptake could be obtained by finding the AGB with Equation (17) and then assigning 20\% to the soil carbon [60]. Equation (20) handles the same growth parameter as Equation (16). Such growth variable of the analyzed species focused mainly on determining the annual growth of mangroves and accounts for both the $\mathrm{DBH}$ and height.

The results in Table 5 indicate the proportionality of the dependent variables compared to the independent ones. For Equations (5) and (6), we saw that AGB is directly proportional to $\rho_{e}$ and proportional to the cube of DBH. In Equation (12), we saw that $V$ is proportional to $h, A_{b a}$, and $A_{m}$, but inversely proportional to $A_{t}$. For the case of Equations (13), (14), and (19) there is a proportionality with respect to the only parameter 
that composes it. The result of Equations (16) and (17) show the proportionality between the most influential parameters that comprise it.

The models found do considered relevant parameters for AGB; however, they do not follow physical relationships entirely as suggested by the dimensional analysis. Most of the allometric equations found did not present dimensional homogeneity in terms of the dependent and independent variables. This leads to the conclusion that the authors did not seek a relationship that would first fulfil the physical dimensionality between dependent and independent variables, but rather functional relationships based purely on statistical foundations. The latter contradicts what Heusner stated in 1987: the physical dimensions of allometric expressions are of great importance, specifically the proportional coefficient relating the dependent and independent variables (alpha) [63]. In this regard, Morgado and Günther, in 1990, stated that "allometric equations only deals with two variables at a time, despite the fact that all biological processes are more likely to be of multivariate nature, and non-physical factors may influence the physical variables which are investigated"; however, it was stated years before (1984) by Schmidt-Nielsen that "dimensional analysis of physics can not be applied to the results of many biological measurements that are expressed in allometric form".

\section{Conclusions}

This investigation presents a critical and systematic review of the aspects considered when modeling mangrove flux processes and environmental interactions. A total of 15 studies were analyzed, where 1 was related to depollution, 11 to biomass content, 1 to a rate of growth, and 1 to carbon sequestration. Each of the models encountered was analyzed regarding mangroves' characteristics (i.e., linearity and similarities).

Among the analyzed studies, it is recommended to use the diameter of the crown instead of the $\mathrm{DBH}$ to have more accurate estimates, which represents a quite controversial assumption since most equations found for the determination of aerial biomass use the $\mathrm{DBH}$ in their calculations. In this case, it is necessary to consider the level of precision wanted to consider modifying the equation, depending on the diameter of the crown.

The variables necessary for structuring a complete model were identified, from simple measurements such as DBH to the determination of concentrations in the soil, density, and others. It will be necessary to reevaluate the variables that should be obtained, depending on the influence they have on the total value of AGB, in order to be more efficient in terms of equipment and time needed in the modeling processes.

The importance of complying with physical dimensionality lies in the fact that the models can be replicable for different species because they take into account intrinsic characteristics of each species such as its density, for example. Including volume, diameter, and height does not characterize a species. This can be achieved by combining the above with correlation analysis. Looking for relationships based solely on statistics indicates, among several things, that we are not concerned with knowing the complete physical relationship between these two variables. It is like a black box model.

It is possible to show the importance of studies to estimate $\mathrm{CO}_{2}$ capture and storage, providing information to governments and other researchers to structure new analysis plans based on models, and not by the traditional invasive destruction method, seeking preservation and recovery of mangrove ecosystems while the information regarding these ecosystems continues to increase. In this way, mangrove forests can continue to mitigate the problems of global warming.

Author Contributions: J.B., M.C.A., and N.T.-F. conceived and designed the investigation, in collaboration with D.M., J.B. prepared the writing—original draft preparation. M.C.A., N.T.-F., and D.M. did the writing - review and editing. The funding acquisition was carried out by N.T.-F. All authors have read and agreed to the published version of the manuscript. 
Funding: This research was funded by the National Research System of Panama and the Panama Research and Integrated Sustainability Model (PRISM) Small Grants of the McGill Sustainability Systems Initiative.

Conflicts of Interest: The authors declare no conflict of interest. The funders had no role in the design of the study; in the collection, analyses, or interpretation of data; in the writing of the manuscript, or in the decision to publish the results.

\section{Appendix A}

Table A1 with information on parameters used in the different equations shown in this research.

Table A1. Parameters used in the equations presented.

\begin{tabular}{|c|c|c|c|}
\hline Parameter & Definition & Units & Source \\
\hline AGB & aboveground biomass & $\mathrm{kg}$ & - \\
\hline AG & annual mangrove growth & - & [6] \\
\hline A, B & constant & - & {$[58]$} \\
\hline$A_{b}$ & forest area & ha & - \\
\hline$A_{d}$ & accretion rate obtained by the radiometric system & $\mathrm{cm} \cdot \mathrm{y}^{-1}$ & - \\
\hline$A_{b a}, A_{m}, A_{t}$ & base, middle, and top areas & $\mathrm{m}^{2}$ & - \\
\hline $\mathrm{b}$ & trophic magnification slope & - & [50] \\
\hline $\mathrm{BD}$ & average bulk density & g-soil $\cdot \mathrm{cm}^{-3}$ & - \\
\hline BAF & bioaccumulation factor & - & [50] \\
\hline BGB & below ground biomass & $\mathrm{kg}$ & - \\
\hline $\mathrm{b}_{2}$ & growth constants of the species & - & [6] \\
\hline$b_{3}$ & growth constants of the species & - & [6] \\
\hline $\mathrm{B}_{\mathrm{i}}$ & initial biomass in the area & ton & - \\
\hline$B_{d b}$ & dry branch biomass & $\mathrm{kg}$ & - \\
\hline $\mathrm{bw}_{\mathrm{j}}$ & average weight of the branches & $\mathrm{kg}$ & - \\
\hline CD & crown diameter & $\mathrm{m}$ & - \\
\hline $\mathrm{C}_{\text {conc }}$ & average concentration of carbon in the soil & $\mathrm{g}-\mathrm{C} \cdot \mathrm{g}$-soil ${ }^{-1}$ & - \\
\hline $\mathrm{C}_{\mathrm{f}}$ & fixed carbon & ton & - \\
\hline $\mathrm{C}_{\text {seq }}$ & carbon sequestration & $\mathrm{g}-\mathrm{C} \cdot \mathrm{cm}^{-2} \cdot \mathrm{y}^{-1}$ & - \\
\hline $\mathrm{DBH}$ & diameter at breast height & $\mathrm{cm}$ & - \\
\hline $\mathrm{D}_{0}$ & diameter just above the soil surface & $\mathrm{cm}$ & - \\
\hline $\mathrm{D}_{\text {Max }}$ & maximum diameter of the species & $\mathrm{cm}$ & - \\
\hline E & bioclimatic variables & - & [52] \\
\hline $\mathrm{EF}$ & enrichment factor & - & {$[50]$} \\
\hline G & annual growth rate & - & [17] \\
\hline $\mathrm{G}_{\mathrm{y}}$ & growth constants of the species & - & [6] \\
\hline $\mathrm{h}$ & stem height & $\mathrm{m}$ & - \\
\hline $\mathrm{H}$ & stem height & $\mathrm{cm}$ & - \\
\hline Hf & hafnium & - & [50] \\
\hline $\mathrm{H}_{\mathrm{Max}}$ & maximum height of the species & $\mathrm{cm}$ & - \\
\hline $\mathrm{K}$ & carbon in biomass $(45 \%)$ & - & - \\
\hline $\mathrm{L}_{\mathrm{db}}$ & dry leaf biomass & $\mathrm{kg}$ & - \\
\hline $\mathrm{Lw}_{\mathrm{j}}$ & average dry weight of extracted leaves & $\mathrm{kg}$ & - \\
\hline $\mathrm{n}$ & effect of nutrients & - & [6] \\
\hline $\mathrm{n}_{\mathrm{j}}$ & number of branches in each tree & - & - \\
\hline $\mathrm{N}_{\mathrm{j}}$ & number of trees & - & - \\
\hline $\mathrm{r}_{\mathrm{el}}$ & effects of light intensity & - & [6] \\
\hline$S$ & effect of salinity & - & [6] \\
\hline $\mathrm{t}$ & time & $\mathrm{y}$ & - \\
\hline $\mathrm{TF}$ & translocation factor & - & [50] \\
\hline$t_{e}$ & temperature effects & - & [6] \\
\hline $\mathrm{V}$ & volume of stem biomass & $\mathrm{m}^{3}$ & - \\
\hline$\delta 13 C$ & stable carbon isotope & - & {$[50]$} \\
\hline$\rho_{\mathrm{e}}$ & tree species density & $\mathrm{g} \cdot \mathrm{cm}^{-3}$ & - \\
\hline
\end{tabular}




\section{References}

1. Altieri, M. Cambio climático y agricultura campesina: Impactos y respuestas adaptativas. LEISA Rev. Agroecol. 2009, 14, 5-8.

2. Castro, M. Derretimiento de Los Polos: Evolución, Causas, Consecuencias, Soluciones-Lifeder. Available online: https://www. lifeder.com/derretimiento-de-los-polos/ (accessed on 17 July 2020).

3. Food and Agriculture Organization of the United Nations. Carbono Organico del Suelo: El Potencial Oculto; Food \& Agriculture Org: Rome, Italy, 2017; ISBN 978-92-5-309681-7.

4. FAO. The World's Mangroves 1980-2005; FAO: Rome, Italy, 2007; ISBN 978-92-5-105856-5.

5. Dat Pham, T.; Xia, J.; Thang Ha, N.; Tien Bui, D.; Nhu Le, N.; Tekeuchi, W. A Review of Remote Sensing Approaches for Monitoring Blue Carbon Ecosystems: Mangroves, Sea Grasses and Salt Marshes during 2010-2018. Sensors 2019, 19 , 1933. [CrossRef] [PubMed]

6. Rodríguez-Rodríguez, J.A.; Mancera-Pineda, J.E.; Rodríguez-P., J.M. Validación y Aplicación de Un Modelo de Restauración de Manglar Basado En Individuos Para Tres Especies En La Ciénaga Grande de Santa Marta. Caldasia 2016, 38, 285-299. [CrossRef]

7. Das, S.; Crépin, A.-S. Mangroves Can Provide Protection against Wind Damage during Storms. Estuar. Coast. Shelf Sci. 2013, 134, 98-107. [CrossRef]

8. Mosquera, L.P.; Riaño-Herrera, N.M.; Arcila-Pulgarín, J.; Ponce-Dávila, C.A.; Fotosíntesis, Respiración y Fotorrespiración. 7. Available online: https:/ / www.cenicafe.org/es / publications/arc050\%2803\%29215-221.pdf (accessed on 14 May 2020).

9. Solarte, M.E.; Moreno, L.; Melgarejo, L.M., VI; Fotosíntesis y Pigmentos Vegetales. 16. Available online: https:/ / www.researchgate. net/publication/295010397_Fotosintesis_y_pigmentos_vegetales (accessed on 14 May 2020).

10. Fetcher, N.; Oberbauer, S.F.; Rojas, G.; Strain, B.R. Efectos Del Régimen de Luz Sobre La Fotosíntesis y El Crecimiento En Plántulas de Árboles de Un Bosque Lluvioso Tropical de Costa Rica. Rev. Biol. Trop. 1987, 35, 97-110.

11. Colombo, R.; Marín, O. Relaciones hídricas, Fotosíntesis, y anatomía foliar de dos especies del género Calotropis. Interciencia 2007, 32, 7 .

12. Mazda, Y.; Wolanski, E. Hydrodynamics and Modeling of Water Flow in Mangrove Areas, 1st ed.; Elsevier: Amsterdam, The Netherlands, 2009; ISBN 978-0-444-53103-2.

13. Ishida, A.; Yamamura, Y.; Hori, Y. Roles of Leaf Water Potential and Soil-to-Leaf Hydraulic Conductance in Water Use by Understorey Woody Plants. Ecol. Res. 1992, 7, 213-223. [CrossRef]

14. Carrasco, O. Transporte de Agua En Plantas. El Balance Hídrico En Tallos de Árboles Nativos Del Norte de Argentina: Uso e Importancia de Los Reservorios Internos de Agua. Ph.D. Thesis, Universidad de Buenos Aires, Buenos Aires, Argentina, 2018.

15. Edwards, W.R.N.; Jarvis, P.G.; Landsberg, J.J.; Talbot, H. A Dynamic Model for Studying Flow of Water in Single Trees. Tree Physiol. 1986, 1, 309-324. [CrossRef]

16. Sobrado, M.A. Relation of Water Transport to Leaf Gas Exchange Properties in Three Mangrove Species. Trees 2000, 14, 0258-0262. [CrossRef]

17. Torres, Y.L. Los Sumideros De Carbono: Un Anàlisis De La Potencialidad Económica En Un Bosque De Manglar Del Pacifico Colombiano. Ing. Recur. Nat. Ambiente 2007, 6, 82-92.

18. Ali, S.A.; Khatun, R.; Ahmad, A.; Ahmad, S.N. Application of GIS-Based Analytic Hierarchy Process and Frequency Ratio Model to Flood Vulnerable Mapping and Risk Area Estimation at Sundarban Region, India. Model. Earth Syst. Environ. 2019, 5, 1083-1102. [CrossRef]

19. Zhang, K.; Gann, D.; Ross, M.; Biswas, H.; Li, Y.; Rhome, J. Comparison of TanDEM-X DEM with LiDAR Data for Accuracy Assessment in a Coastal Urban Area. Remote Sens. 2019, 11, 876. [CrossRef]

20. Deb Burman, P.K.; Sarma, D.; Williams, M.; Karipot, A.; Chakraborty, S. Estimating Gross Primary Productivity of a Tropical Forest Ecosystem over North-East India Using LAI and Meteorological Variables. J. Earth Syst. Sci. 2017, 126, 99. [CrossRef]

21. Fatoyinbo, T.; Feliciano, E.A.; Lagomasino, D.; Lee, S.K.; Trettin, C. Estimating Mangrove Aboveground Biomass from Airborne LiDAR Data: A Case Study from the Zambezi River Delta. Environ. Res. Lett. 2018, 13, 025012. [CrossRef]

22. Wong, C.J.; James, D.; Besar, N.A.; Kamlun, K.U.; Tangah, J.; Tsuyuki, S.; Phua, M.-H. Estimating Mangrove Above-Ground Biomass Loss Due to Deforestation in Malaysian Northern Borneo between 2000 and 2015 Using SRTM and Landsat Images. Forests 2020, 11, 1018. [CrossRef]

23. Gress, S.K.; Huxham, M.; Kairo, J.G.; Mugi, L.M.; Briers, R.A. Evaluating, Predicting and Mapping Belowground Carbon Stores in Kenyan Mangroves. Glob. Chang. Biol. 2017, 23, 224-234. [CrossRef] [PubMed]

24. Adegboyega, S.A.; Oloukoi, J.; Olajuyigbe, A.E.; Ajibade, O.E. Evaluation of Unsustainable Land Use/Land Cover Change on Ecosystem Services in Coastal Area of Lagos State, Nigeria. Appl. Geomat. 2019, 11, 97-110. [CrossRef]

25. Nurda, N.; Noguchi, R.; Ahamed, T. Forest Productivity and Carbon Stock Analysis from Vegetation Phenological Indices Using Satellite Remote Sensing in Indonesia. Asia-Pac. J. Reg. Sci. 2020, 4, 657-690. [CrossRef]

26. Etemadi, H.; Smoak, J.M.; Karami, J. Land Use Change Assessment in Coastal Mangrove Forests of Iran Utilizing Satellite Imagery and CA-Markov Algorithms to Monitor and Predict Future Change. Environ. Earth Sci. 2018, 77, 208. [CrossRef]

27. Wicaksono, P. Mangrove Above-Ground Carbon Stock Mapping of Multi-Resolution Passive Remote-Sensing Systems. Int. J. Remote Sens. 2017, 38, 1551-1578. [CrossRef]

28. Wicaksono, P.; Danoedoro, P.; Hartono, H.; Nehren, U. Mangrove Biomass Carbon Stock Mapping of the Karimunjawa Islands Using Multispectral Remote Sensing. Int. J. Remote Sens. 2016, 37, 26-52. [CrossRef] 
29. Slamet, N.S.; Dargusch, P.; Aziz, A.A.; Wadley, D. Mangrove Vulnerability and Potential Carbon Stock Loss from Land Reclamation in Jakarta Bay, Indonesia. Ocean Coast. Manag. 2020, 195, 105283. [CrossRef]

30. Soper, F.M.; MacKenzie, R.A.; Sharma, S.; Cole, T.G.; Litton, C.M.; Sparks, J.P. Non-Native Mangroves Support Carbon Storage, Sediment Carbon Burial, and Accretion of Coastal Ecosystems. Glob. Chang. Biol. 2019, 25, 4315-4326. [CrossRef]

31. Wang, M.; Cao, W.; Guan, Q.; Wu, G.; Jiang, C.; Yan, Y.; Su, X. Potential of Texture Metrics Derived from High-Resolution PLEIADES Satellite Data for Quantifying Aboveground Carbon of Kandelia Candel Mangrove Forests in Southeast China. Wetl. Ecol. Manag. 2018, 26, 789-803. [CrossRef]

32. Cao, B.; Domke, G.M.; Russell, M.B.; Walters, B.F. Spatial Modeling of Litter and Soil Carbon Stocks on Forest Land in the Conterminous United States. Sci. Total Environ. 2019, 654, 94-106. [CrossRef] [PubMed]

33. Elmahdy, S.I.; Ali, T.A.; Mohamed, M.M.; Howari, F.M.; Abouleish, M.; Simonet, D. Spatiotemporal Mapping and Monitoring of Mangrove Forests Changes From 1990 to 2019 in the Northern Emirates, UAE Using Random Forest, Kernel Logistic Regression and Naive Bayes Tree Models. Front. Environ. Sci. 2020, 8, 1-23. [CrossRef]

34. Sidik, F.; Fernanda Adame, M.; Lovelock, C.E. Carbon Sequestration and Fluxes of Restored Mangroves in Abandoned Aquaculture Ponds. J. Indian Ocean Reg. 2019, 15, 177-192. [CrossRef]

35. Mohanta, M.R.; Mohanta, A.; Mohapatra, U.; Mohanty, R.C.; Sahu, S.C. Carbon Stock Assessment and Its Relation with Tree Biodiversity in Tropical Moist Deciduous Forest of Similipal Biosphere Reserve, Odisha, India. Trop. Ecol. 2020, 61, 497-508. [CrossRef]

36. Simpson, L.T.; Osborne, T.Z.; Duckett, L.J.; Feller, I.C. Carbon Storages along a Climate Induced Coastal Wetland Gradient. Wetlands 2017, 37, 1023-1035. [CrossRef]

37. Ravelo, F.N.; Pérez, M.U.; Quiroz, D.; Vásquez, B.; Belmonte, D. CO \textlessinf $\backslash$ textgreater2 $\backslash$ textless /Inf $\backslash$ textgreater Flow in Soils Dominated by Mangroves Avicennia Germinans and Conocarpus Erectus [Flujo de CO $\backslash$ textlessinf $\backslash$ textgreater2 $\backslash$ textless/Inf $\backslash$ textgreater En Suelos Dominados Por Manglares Avicennia Germinans y Conocarpus Erectus]. Rev. Geogr. Venez. 2019, 60, $284-299$.

38. Wang, G.; Guan, D.; Xiao, L.; Peart, M.R. Ecosystem Carbon Storage Affected by Intertidal Locations and Climatic Factors in Three Estuarine Mangrove Forests of South China. Reg. Environ. Chang. 2019, 19, 1701-1712. [CrossRef]

39. Rovai, A.S.; Coelho, C., Jr.; de Almeida, R.; Cunha-Lignon, M.; Menghini, R.P.; Twilley, R.R.; Cintrón-Molero, G.; SchaefferNovelli, Y. Ecosystem-Level Carbon Stocks and Sequestration Rates in Mangroves in the Cananéia-Iguape Lagoon Estuarine System, Southeastern Brazil. For. Ecol. Manag. 2021, 479, 118553. [CrossRef]

40. Shaltout, K.H.; Ahmed, M.T.; Alrumman, S.A.; Ahmed, D.A.; Eid, E.M. Evaluation of the Carbon Sequestration Capacity of Arid Mangroves along Nutrient Availability and Salinity Gradients along the Red Sea Coastline of Saudi Arabia. Oceanologia 2020, 62, 56-69. [CrossRef]

41. Sheehan, L.; Sherwood, E.T.; Moyer, R.P.; Radabaugh, K.R.; Simpson, S. Blue Carbon: An Additional Driver for Restoring and Preserving Ecological Services of Coastal Wetlands in Tampa Bay (Florida, USA). Wetlands 2019, 39, 1317-1328. [CrossRef]

42. Herrera Silveira, J.A.; Rico, A.C.; Pech, E.; Pech, M.; Ramírez, J.R.; Hernández, C.T. Carbon Dynamics (Stocks and Fluxes) in Mangroves of Mexico [Dinámica Del Carbono (Almacenes y Flujos) En Manglares de México]. Terra Latinoam. 2016, $34,61-72$.

43. Thorhaug, A.; Gallagher, J.B.; Kiswara, W.; Prathep, A.; Huang, X.; Yap, T.-K.; Dorward, S.; Berlyn, G. Coastal and Estuarine Blue Carbon Stocks in the Greater Southeast Asia Region: Seagrasses and Mangroves per Nation and Sum of Total. Mar. Pollut. Bull. 2020, 160, 111168. [CrossRef]

44. Bhomia, R.K.; Kauffman, J.B.; McFadden, T.N. Ecosystem Carbon Stocks of Mangrove Forests along the Pacific and Caribbean Coasts of Honduras. Wetl. Ecol. Manag. 2016, 24, 187-201. [CrossRef]

45. Wang, Q.; Zeng, J.; Leng, S.; Fan, B.; Tang, J.; Jiang, C.; Huang, Y.; Zhang, Q.; Qu, Y.; Wang, W.; et al. The Effects of Air Temperature and Precipitation on the Net Primary Productivity in China during the Early 21st Century. Front. Earth Sci. 2018, 12, 818-833. [CrossRef]

46. Zhao, H.; Yang, S.; Guo, X.; Peng, C.; Gu, X.; Deng, C.; Chen, L. Anatomical Explanations for Acute Depressions in Radial Pattern of Axial Sap Flow in Two Diffuse-Porous Mangrove Species: Implications for Water Use. Tree Physiol. 2018, 38, $277-287$. [CrossRef]

47. Gnanamoorthy, P.; Selvam, V.; Ramasubramanian, R.; Nagarajan, R.; Chakraborty, S.; Deb Burman, P.K.; Karipot, A. Diurnal and Seasonal Patterns of Soil $\mathrm{CO} \backslash$ textlessinf $\backslash$ textgreater2 $\backslash$ textless/Inf $\backslash$ textgreater Efflux from the Pichavaram Mangroves, India. Environ. Monit. Assess. 2019, 191, 258. [CrossRef] [PubMed]

48. Thorhaug, A.L.; Poulos, H.M.; López-Portillo, J.; Barr, J.; Lara-Domínguez, A.L.; Ku, T.C.; Berlyn, G.P. Gulf of Mexico Estuarine Blue Carbon Stock, Extent and Flux: Mangroves, Marshes, and Seagrasses: A North American Hotspot. Sci. Total Environ. 2019, 653, 1253-1261. [CrossRef] [PubMed]

49. Couvreur, V.; Ledder, G.; Manzoni, S.; Way, D.A.; Muller, E.B.; Russo, S.E. Water Transport through Tall Trees: A Vertically Explicit, Analytical Model of Xylem Hydraulic Conductance in Stems. Plant Cell Environ. 2018, 41, 1821-1839. [CrossRef] [PubMed]

50. Ray, R.; Dutta, B.; Mandal, S.K.; González, A.G.; Pokrovsky, O.S.; Jana, T.K. Bioaccumulation of Vanadium (V), Niobium (Nb) and Tantalum (Ta) in Diverse Mangroves of the Indian Sundarbans. Plant Soil 2020, 448, 553-564. [CrossRef]

51. Pittarello, M.; Busato, J.G.; Carletti, P.; Sodré, F.F.; Dobbss, L.B. Dissolved Humic Substances Supplied as Potential Enhancers of $\mathrm{Cu}, \mathrm{Cd}$, and Pb Adsorption by Two Different Mangrove Sediments. J. Soils Sedim. 2019, 19, 1554-1565. [CrossRef]

52. Mohd Zaki, N.A.; Abd Latif, Z.; Suratman, M.N.; Zainal, M.Z. Aboveground Biomass and Carbon Stocks Modelling Using Non-Linear Regression Model. In IOP Conference Series: Earth and Environmental Science; IOP: London, UK, 2016 ; Volume 37. 
53. da Motta Portillo, J.T.; Londe, V.; Moreira, F.W.A. Aboveground Biomass and Carbon Stock Are Related with Soil Humidity in a Mangrove at the Piraquê-Açu River, Southeastern Brazil. J. Coast. Conserv. 2017, 21, 139-144. [CrossRef]

54. Vinh, T.V.; Marchand, C.; Linh, T.V.K.; Vinh, D.D.; Allenbach, M. Allometric Models to Estimate Above-Ground Biomass and Carbon Stocks in Rhizophora Apiculata Tropical Managed Mangrove Forests (Southern Viet Nam). For. Ecol. Manag. 2019, 434, 131-141. [CrossRef]

55. Simpson, L.T.; Stein, C.M.; Osborne, T.Z.; Feller, I.C. Mangroves Dramatically Increase Carbon Storage after 3 Years of Encroachment. Hydrobiologia 2019, 834, 13-26. [CrossRef]

56. Chatting, M.; LeVay, L.; Walton, M.; Skov, M.W.; Kennedy, H.; Wilson, S.; Al-Maslamani, I. Mangrove Carbon Stocks and Biomass Partitioning in an Extreme Environment. Estuar. Coastal Shelf Sci. 2020, 244, 106940. [CrossRef]

57. Kelleway, J.J.; Saintilan, N.; Macreadie, P.I.; Skilbeck, C.G.; Zawadzki, A.; Ralph, P.J. Seventy Years of Continuous Encroachment Substantially Increases "blue Carbon" Capacity as Mangroves Replace Intertidal Salt Marshes. Glob. Chang. Biol. 2016, 22, 1097-1109. [CrossRef]

58. Clough, B.F; Dixon, P.; Dalhaus, O. Allometric Relationships for Estimating Biomass in Multi-Stemmed Mangrove Trees. Aust. J. Bot. 1997, 45, 1023. [CrossRef]

59. Prasanna, J.; Anand, M.; Vijayasekaran, D.; Kumaraguru, A.K. Allometric Model for Estimating above Ground Biomass and Carbon Storage in Karankadu Mangrove Swamp, Palk Bay, Southeast Coast of India. Indian J. Geo-Mar. Sci. 2017, 46, 1682-1692.

60. Makinde, E.O.; Womiloju, A.A.; Ogundeko, M.O. The Geospatial Modelling of Carbon Sequestration in Oluwa Forest, Ondo State, Nigeria. Eur. J. Remote Sens. 2017, 50, 397-413. [CrossRef]

61. Kusmana, C.; Hidayat, T.; Tiryana, T.; Rusdiana, O. Istomo Allometric Models for Above- and below-Ground Biomass of Sonneratia Spp. Glob. Ecol. Conserv. 2018, 15, 15. [CrossRef]

62. Marchio, D.A.; Savarese, M.; Bovard, B.; Mitsch, W.J. Carbon Sequestration and Sedimentation in Mangrove Swamps Influenced by Hydrogeomorphic Conditions and Urbanization in Southwest Florida. Forests 2016, 7, 116. [CrossRef]

63. Morgado, E.; Günther, B. On the Hidden Physical Dimensions of the Allometric Equation. Arch. Biol. Med. Exp. 1990, 23, 29-39. 